\title{
Tissue composition of sponges from the Weddell Sea, Antarctica: not much meat on the bones
}

\author{
Dagmar Barthel
}

Institut für Meereskunde, Düsternbrooker Weg 20, D-24105 Kiel, Germany

\begin{abstract}
The tissue of 31 demosponge and 7 hexactinellid species was analyzed for its composition of organic and inorganic matter. With one exception (Haliclona cf. gaussiana) inorganic matter, i.e. mostly the siliceous skeleton, accounted for most of the dry weight, varying between about 60 and $95 \%$ dry wt. There were no general trends in the ratio of organic to inorganic matter within sponge orders or genera, and within one species, the ratio could vary between stations. For one of the hexactinellids, Bathydorus spinosus, several size classes were analyzed and there was no systematic change in the organic: inorganic matter ratio with specimen size. For some species the results from the Weddell Sea sponges are in good agreement with earlier data from McMurdo Sound. The low organic matter content in Weddell Sea sponges implies that sponge biomasses are much lower than hitherto assumed on the basis of their high abundances and large sizes. In consequence, Antarctic sponges, despite their ubiquitousness, may only channel a minor fraction of the general bentho-pelagic flow of matter and energy, and their main role in the ecosystem is likely structural rather than dynamic.
\end{abstract}

KEY WORDS: Sponges - Antarctica - Tissue composition - Demosponges - Hexactinellids - lnorganic skeleton

\section{INTRODUCTION}

Sponges are dominant members of many Antarctic benthic communities (Beliaev \& Ushakov 1957, Koltun 1969, 1970, Dayton et al. 1970, Voss 1988, Barthel et al. 1990). Most of the ca 300 different species known from the Antarctic are demosponges; only 28 species of hexactinellids are currently recognized (Barthel \& Tendal 1994). Although only represented by comparatively few species, hexactinellids are important structural agents in this ecosystem. When living, they serve as a habitat for numerous other benthic organisms (Dearborn 1977, Gutt 1988, Wägele 1988, Barthel et al. 1991, Kunzmann 1992); the persistent skeletons of dead hexactinellids form the major part of the wellknown Antarctic spicule mats, thereby modifying the substrate conditions for other benthic fauna (Barthel 1992a, b, Barthel \& Gutt 1992). The demosponge species investigated by Kunzmann (1992) harbour a less rich fauna, and demosponge skeletons, composed of mostly small spicules, do not have the same structural properties as those of hexactinellids.
While we possess some information on the structural role of sponges in Antarctic benthic ecosystems, we have virtually no knowledge on their participation in the flow of matter and energy from the pelagic to the benthic realm. A noteworthy exception is the now classic study by Dayton et al. (1974), which gives data on tissue composition, growth rates, abundances of and predation on a number of sponges from the shallow part of McMurdo Sound.

In this contribution, data on the body composition of 37 dominant sponge species from the eastern Weddell Sea shelf are presented as a first step towards assessing their role in benthopelagic coupling.

\section{MATERIAL AND METHODS}

Sponge material was collected during leg 3 of the 'European Polarstern Study' (EPOS) cruise along the eastern Weddell Sea shelf. Particulars on sites and station lists are compiled in Arntz et al. (1990). The sponges were dredged with either Agassiz or large 
Table 1 Tissue composition of Antarctic demosponges (means \pm SD). Depth values are depth at beginning and end of bottom time. A: Agassiz trawl; G: large bottom trawl; B: benthopelagic trawl

\begin{tabular}{|c|c|c|c|c|c|c|c|}
\hline Species & $\begin{array}{l}\text { Stn and } \\
\text { trawl type }\end{array}$ & $\begin{array}{l}\text { Depth } \\
(\mathrm{m})\end{array}$ & $\begin{array}{c}\text { DW } \\
(\% W W)\end{array}$ & $\begin{array}{l}\text { AFDW } \\
(\% \text { DW })\end{array}$ & \multicolumn{2}{|c|}{ Ash } & $\mathrm{n}$ \\
\hline \multicolumn{8}{|l|}{ Choristida } \\
\hline Monosyringa longispina & $284 \mathrm{G}$ & $402-412$ & $22.31 \pm 3.03$ & $25.49 \pm 3.46$ & $74.52 \pm 3.46$ & $16.66 \pm 2.64$ & 6 \\
\hline \multicolumn{8}{|l|}{ Spirophorida } \\
\hline \multirow[t]{5}{*}{ Tetilla leptoderma } & $293 \mathrm{G}$ & $771-793$ & $24.74 \pm 5.88$ & $25.34 \pm 1.86$ & $74.66 \pm 1.86$ & $18.53 \pm 4.65$ & 21 \\
\hline & $249 \mathrm{G}$ & $499-515$ & 26.46 & 16.69 & 83.31 & 22.09 & 3 \\
\hline & $274 \mathrm{~A}$ & $196-212$ & $20.81 \pm 4.78$ & $23.95 \pm 6.02$ & $76.05 \pm 6.02$ & $16.01 \pm 4.77$ & 11 \\
\hline & $211 \mathrm{G}$ & $207-213$ & $50.86 \pm 18.27$ & $14.89 \pm 0.63$ & $85.11 \pm 0.63$ & $43.23 \pm 15.37$ & 5 \\
\hline & $235 \mathrm{G}$ & $405-407$ & $33.04 \pm 2.79$ & $34.16 \pm 4.19$ & $65.84 \pm 4.19$ & $21.83 \pm 3.03$ & 8 \\
\hline Tetillid sp. & $241 \mathrm{G}$ & $451-453$ & 17.56 & 23.21 & 76.79 & 13.50 & 3 \\
\hline Cinachyra antarctica & $274 \mathrm{~A}$ & $196-212$ & $29.64 \pm 5.12$ & $39.67 \pm 2.63$ & $60.33 \pm 2.63$ & $17.92 \pm 3.41$ & 13 \\
\hline \multirow[t]{2}{*}{ Cinachyra barbata } & $274 \mathrm{~A}$ & $196-212$ & $30.43 \pm 7.56$ & $16.85 \pm 4.39$ & $83.15 \pm 4.39$ & $25.45 \pm 7.19$ & 12 \\
\hline & $224 \mathrm{G}$ & $186-187$ & 35.02 & 29.87 & 70.13 & 24.31 & 2 \\
\hline \multicolumn{8}{|l|}{ Hadromerida } \\
\hline Polymastia invaginata & $235 \mathrm{G}$ & $405-407$ & $35.55 \pm 2.41$ & $16.01 \pm 4.54$ & $83.99 \pm 4.54$ & $29.91 \pm 3.15$ & 10 \\
\hline Polymastia isidis & $275 \mathrm{~A}$ & $301-330$ & 39.37 & 10.27 & 89.73 & 35.37 & 2 \\
\hline \multirow[t]{2}{*}{ Tentorium papillatum } & $241 \mathrm{G}$ & $451-453$ & $32.80 \pm 4.11$ & $38.14 \pm 4.00$ & $61.86 \pm 4.00$ & $20.44 \pm 3.73$ & 5 \\
\hline & $235 \mathrm{~A}$ & $399-404$ & 37.25 & 32.48 & 67.52 & 25.24 & 3 \\
\hline Suberites sp. & $241 \mathrm{G}$ & $451-453$ & 24.58 & 19.22 & 80.78 & 19.84 & 2 \\
\hline Pseudosuberites nudus & $248 \mathrm{G}$ & $599-602$ & $52.73 \pm 3.71$ & $6.06 \pm 2.76$ & $93.94 \pm 2.76$ & $49.56 \pm 4.17$ & 5 \\
\hline Latrunculia apicalis (red) & $261 \mathrm{~B}$ & $798-799$ & $22.59 \pm 3.82$ & $27.08 \pm 5.16$ & $72.92 \pm 5.16$ & $16.62 \pm 3.88$ & 5 \\
\hline \multicolumn{7}{|l|}{ Poecilosclerida } & \\
\hline Mycale acerata & $272 \mathrm{~A}$ & $406-409$ & 24.29 & 16.80 & 83.20 & 20.20 & 2 \\
\hline \multirow[t]{2}{*}{ Isodictya erinacea } & 284 G & $402-412$ & 47.12 & 15.12 & 84.88 & 40.10 & 2 \\
\hline & $241 \mathrm{G}$ & $451-453$ & $39.76 \pm 4.49$ & $18.25 \pm 2.85$ & $81.75 \pm 2.85$ & $32.58 \pm 4.44$ & 16 \\
\hline Isodictya cavicornuta & $258 \mathrm{~B}$ & $484-509$ & $17.84 \pm 3.30$ & $22.93 \pm 4.13$ & $77.07 \pm 4.13$ & $13.70 \pm 2.32$ & 18 \\
\hline \multirow[t]{6}{*}{ Isodictya toxophila } & $284 \mathrm{G}$ & $402-412$ & 41.01 & 14.30 & 85.70 & 35.23 & 2 \\
\hline & $235 \mathrm{G}$ & $405-407$ & $45.30 \pm 7.30$ & $8.63 \pm 3.15$ & $91.37 \pm 3.15$ & $41.31 \pm 6.28$ & 9 \\
\hline & $245 \mathrm{~A}$ & $483-484$ & $39.18 \pm 3.24$ & $12.87 \pm 1.01$ & $87.13 \pm 1.01$ & $34.69 \pm 2.96$ & 11 \\
\hline & $291 G$ & $499-515$ & 41.66 & 14.04 & 85.97 & 35.81 & 2 \\
\hline & $248 \mathrm{G}$ & $599-602$ & $29.90 \pm 4.13$ & $9.13 \pm 0.70$ & $90.87 \pm 0.70$ & $27.19 \pm 3.92$ & 5 \\
\hline & $249 G$ & $701-702$ & $33.43 \pm 1.53$ & $8.03 \pm 0.36$ & $91.97 \pm 0.36$ & $30.75 \pm 1.50$ & 4 \\
\hline Desmacidon ramosa & $275 \mathrm{~A}$ & $301-330$ & 23.20 & 18.44 & 81.56 & 18.93 & 1 \\
\hline Myxodoryx hanitschi & $272 \mathrm{~A}$ & $406-409$ & 24.62 & 14.78 & 85.22 & 21.06 & 3 \\
\hline Tedania tantula & $271 \mathrm{~A}$ & $352-399$ & $23.96 \pm 6.56$ & $17.70 \pm 1.94$ & $82.30 \pm 1.94$ & $19.75 \pm 5.54$ & 11 \\
\hline & $235 \mathrm{G}$ & $405-407$ & $27.02 \pm 5.98$ & $14.74 \pm 2.52$ & $85.26 \pm 2.52$ & $23.16 \pm 5.74$ & 6 \\
\hline Tedania oxeata & $229 \mathrm{~A}$ & $500-509$ & $27.97 \pm 5.69$ & $10.54 \pm 2.65$ & $89.46 \pm 2.65$ & $25.15 \pm 5.85$ & 9 \\
\hline & $235 \mathrm{G}$ & $405-407$ & $32.82 \pm 8.19$ & $7.36 \pm 2.58$ & $92.64 \pm 2.58$ & $30.59 \pm 8.50$ & 5 \\
\hline & $275 \mathrm{~A}$ & $301-330$ & 32.22 & 11.74 & 88.26 & 20.68 & 3 \\
\hline & $235 \mathrm{~A}$ & $399-404$ & $40.90 \pm 4.19$ & $6.25 \pm 1.31$ & $93.75 \pm 1.31$ & $38.37 \pm 4.35$ & 7 \\
\hline & $256 \mathrm{~B}$ & $382-399$ & 15.72 & 14.79 & 85.21 & 13.45 & 3 \\
\hline Tedania vanhoeffeni & $256 \mathrm{~B}$ & $382-399$ & $10.89 \pm 1.51$ & $33.92 \pm 3.41$ & $66.08 \pm 3.41$ & $7.19 \pm 1.06$ & 6 \\
\hline Tedania triraphis & $241 \mathrm{~A}$ & $457-462$ & $15.54 \pm 1.10$ & $28.63 \pm 2.77$ & $71.37 \pm 2.77$ & $10.70 \pm 1.03$ & 4 \\
\hline & $271 \mathrm{~A}$ & $352-399$ & $17.30 \pm 7.51$ & $32.34 \pm 14.34$ & $67.66 \pm 14.34$ & $9.46 \pm 2.23$ & 5 \\
\hline Artemisina plumosa & $248 \mathrm{G}$ & $599-602$ & $44.22 \pm 6.04$ & $13.81 \pm 2.68$ & $86.19 \pm 2.68$ & $38.17 \pm 5.68$ & 13 \\
\hline & $241 \mathrm{G}$ & $451-453$ & $24.39 \pm 2.11$ & $23.79 \pm 0.94$ & $76.21 \pm 0.94$ & $18.58 \pm 1.58$ & 4 \\
\hline Artemisina apolloni & $235 \mathrm{~A}$ & $399-404$ & 35.74 & 7.14 & 92.86 & 33.19 & 1 \\
\hline Ectyodoryx ramilobosa & $249 G$ & $701-702$ & $22.57 \pm 5.56$ & $15.24 \pm 2.83$ & $84.76 \pm 2.83$ & $19.03 \pm 4.17$ & 5 \\
\hline & $235 G$ & $405-407$ & $44.52 \pm 2.32$ & $14.55 \pm 1.91$ & $85.45 \pm 1.91$ & $37.87 \pm 1.15$ & 3 \\
\hline Iophon spatulatus & $241 \mathrm{G}$ & $451-453$ & 24.58 & 19.22 & 80.78 & 19.84 & 1 \\
\hline & $271 \mathrm{~A}$ & $352-399$ & 11.63 & 18.61 & 81.39 & 9.46 & 1 \\
\hline Phorbas glaberima & $261 \mathrm{~B}$ & $798-799$ & $30.35 \pm 10.26$ & $16.59 \pm 5.32$ & $83.41 \pm 5.32$ & $25.81 \pm 9.52$ & 6 \\
\hline Haplosclerida & & & & & & & \\
\hline Haliclona cf. gaussiana & $235 \mathrm{~A}$ & $399-404$ & 22.02 & 52.24 & 47.76 & 10.52 & 1 \\
\hline (Hemi) Gellius rudis & $235 \mathrm{G}$ & $405-407$ & $29.27 \pm 6.07$ & $14.00 \pm 1.76$ & $86.00 \pm 1.76$ & $25.19 \pm 5.31$ & 9 \\
\hline & $241 \mathrm{~A}$ & $457-462$ & $19.05 \pm 5.72$ & $10.17 \pm 1.84$ & $89.83 \pm 1.84$ & $17.09 \pm 5.15$ & 11 \\
\hline Hemigellius flagellifer & $229 \mathrm{~A}$ & $500-509$ & $45.26 \pm 10.04$ & $9.99 \pm 0.83$ & $91.01 \pm 0.83$ & $41.24 \pm 9.48$ & 4 \\
\hline Xestospongia cf. coralloides & $249 \mathrm{G}$ & $701-702$ & 19.21 & 14.48 & 85.52 & 16.43 & 1 \\
\hline
\end{tabular}


Table 2. Tissue composition of Antarctic hexactinellids (means \pm SD). Depth values are depth at beginning and end of bottom time. A: Agassiz trawl; G: large bottom trawl; B: benthopelagic trawl

\begin{tabular}{|c|c|c|c|c|c|c|c|}
\hline Species & $\begin{array}{l}\text { Stn and } \\
\text { trawl type }\end{array}$ & $\begin{array}{l}\text { Depth } \\
(\mathrm{m})\end{array}$ & $\begin{array}{c}\text { DW } \\
(\% W W)\end{array}$ & $\begin{array}{c}\text { AFDW } \\
(\% \text { DW })\end{array}$ & $(\% \mathrm{DW})$ & $(\% \mathrm{WW})$ & $n$ \\
\hline \multirow[t]{3}{*}{ Rossella racovitzae } & $248 \mathrm{G}$ & $599-602$ & 41.24 & 4.84 & 95.16 & 38.35 & 1 \\
\hline & $253 \mathrm{~A}$ & $1996-2012$ & 36.74 & 19.32 & 80.68 & 29.64 & 1 \\
\hline & $256 \mathrm{~B}$ & $382-399$ & $31.69 \pm 2.44$ & $23.06 \pm 7.14$ & $76.94 \pm 7.14$ & $24.53 \pm 4.17$ & 5 \\
\hline Rossella villosa & $230 \mathrm{~A}$ & $270-280$ & $30.63 \pm 6.03$ & $14.64 \pm 1.80$ & $85.36 \pm 1.80$ & $26.20 \pm 5.46$ & 5 \\
\hline \multirow[t]{2}{*}{ Rossella fibulata } & $230 \mathrm{~A}$ & $270-280$ & $34.81 \pm 5.39$ & $19.04 \pm 4.86$ & $80.96 \pm 4.86$ & $28.43 \pm 6.15$ & 4 \\
\hline & $281 \mathrm{~A}$ & $389-450$ & $22.98 \pm 1.83$ & $26.71 \pm 1.47$ & $73.29 \pm 1.47$ & $16.87 \pm 1.63$ & 6 \\
\hline \multirow[t]{3}{*}{ Rossella nuda } & $226 \mathrm{G}$ & $569-574$ & $40.03 \pm 15.75$ & $8.41 \pm 1.44$ & $91.59 \pm 1.44$ & $36.83 \pm 14.99$ & 4 \\
\hline & $230 \mathrm{~A}$ & $270-280$ & $30.54 \pm 6.46$ & $18.65 \pm 4.00$ & $81.35 \pm 4.00$ & $24.96 \pm 6.16$ & 16 \\
\hline & $281 \mathrm{~A}$ & $389-450$ & 25.54 & 25.94 & 74.06 & 18.92 & 1 \\
\hline Rossella vanhoeffeni & $274 \mathrm{~A}$ & $196-212$ & 24.26 & 30.38 & 69.62 & 16.88 & 2 \\
\hline Bathydorus spinosus & $258 \mathrm{~B}$ & $484-509$ & & & & & \\
\hline $0-2 \mathrm{~cm}$ & & & $25.62 \pm 4.21$ & $19.39 \pm 2.19$ & $80.61 \pm 2.19$ & $20.65 \pm 3.44$ & 11 \\
\hline $2-4 \mathrm{~cm}$ & & & $23.67 \pm 4.14$ & $23.05 \pm 15.40$ & $76.95 \pm 15.40$ & $18.33 \pm 4.93$ & 17 \\
\hline $4-6 \mathrm{~cm}$ & & & $25.49 \pm 7.47$ & $21.68 \pm 3.15$ & $78.32 \pm 3.15$ & $19.94 \pm 5.91$ & 14 \\
\hline $8-10 \mathrm{~cm}$ & & & 32.72 & 31.52 & 68.48 & 22.40 & 1 \\
\hline $10-12 \mathrm{~cm}$ & & & 25.72 & 24.46 & 75.54 & 19.43 & 1 \\
\hline Scolymastra joubini & $281 \mathrm{~A}$ & $389-423$ & $20.04 \pm 0.53$ & $27.68 \pm 1.39$ & $72.32 \pm 1.39$ & $14.50 \pm 0.51$ & 4 \\
\hline
\end{tabular}

bottom trawls, cleaned and frozen either whole or in part, depending on size. In species possessing long anchoring spicule tufts, care was taken to include these tufts. However, the specimens were torn from the bottom by the trawl and thus the whole spicule tuft may not always have been included. Visibly incomplete specimens were not included in the analysis. In the laboratory, wet weight (WW) was determined. Then, the sponges were freeze-dried and thereafter completely dried in a drying oven for $24 \mathrm{~h}$ at $100^{\circ} \mathrm{C}$ and the dry weight (DW) was measured. Ash-free dry weight (AFDW) and ash content were determined after burning the material in a muffle furnace $\left(500^{\circ} \mathrm{C}, 24 \mathrm{~h}\right)$.

\section{RESULTS}

Tables $1 \& 2$ give the tissue composition of demosponges and hexactinellids respectively. The organic matter content, i.e. cellular material and organic skele. ton, was low, ranging from $4.84 \%$ in the hexactinellid Rossella racovitzae to $52.24 \%$ in the demosponge $\mathrm{HaI}$ iclona cf. gaussiana. There was no homogeneity of tissue composition within orders or even genera. A good example is the genus Tedania, represented by 4 species. T. tantula and T. oxeata have a hard, almost brittle consistency. Between 82.30 and $93.75 \%$ of their dry weight consisted of inorganic skeletal material. The 2 other congeners, $T$. vanhoeffeni and $T$. triraphis, are large, soft-bodied species which exude copious quantities of slime when disturbed (Barthel \& Gutt 1992). In these species the content of inorganic material varied between 66.08 and $71.37 \%$ DW, i.e. was considerably lower. Within any one species, tissue composition could vary between stations. Usually the variation was small and could not be related to the only known factor, depth, as can be seen from the data on the poecilosclerid Isodictya toxophila and the spirophorid Tetilla leptoderma, sampled from 6 and 5 different depths, respectively.

In most cases there was not enough material to investigate the influence of specimen size on tissue composition. This was only possible in the case of the hexactinellid Bathydorus spinosus, which occurred in large quantities at Stn. 258, and for this species, no systematic change of body composition with size could be found (Table 1).

The hexactinellids included in this study all had a low organic matter content, between 4.84 and $31.52 \%$ DW. It is noteworthy that one of the highest values, $30.38 \%$ DW, occurred in the softest of the hexactinellids, Rossella vanhoeffeni, a species we hardly ever found as complete specimens - only fragments - and which possesses only a negligible anchoring spicule tuft.

\section{DISCUSSION}

The data on the body composition of Antarctic sponges show that the organic matter content is, on average, rather low (below 40\%), compared with the few available data on sponges from temperate and tropical waters. The only exception is Haliclona cf. gaussiana, where the organic matter constitutes $52.24 \%$ DW. Arndt (1930), who compiled data on 6 demosponge species from shallow temperate waters, 
Table 3. Ash content of Antarctic demosponges and hexactinellids. Comparison of data from shallow water in McMurdo Sound (Dayton et al. 1974, McClintock 1987) and deeper water in the Weddell Sea. Given are means (or ranges in cases where specimens from more than 1 station were analyzed). Numbers in parentheses are number of specimens investigated

\begin{tabular}{|lccc|}
\hline Species & \multicolumn{3}{c|}{$\begin{array}{c}\text { Ash (\% DW) } \\
\text { (Dayton et al. 1974) }\end{array}$} \\
$\begin{array}{lccc}\text { McMurdo Sound } \\
\text { (McClintock 1987) }\end{array}$ & $\begin{array}{c}\text { Weddell Sea } \\
\text { (this study) }\end{array}$ \\
\hline Tetilla leptoderma & $76.72(5)$ & $52.2(3)$ & $65.84-85.11(48)$ \\
Cinachyra antarctica & $70.26(3)$ & $73.0(3)$ & $60.33(13)$ \\
Mycale acerata & $82.88(4)$ & $68.2(3)$ & $83.20(2)$ \\
Polymastia invaginata & $85.21(3)$ & - & $83.99(10)$ \\
Latrunculia apicalis & - & $49.8(3)$ & $72.92(5)$ \\
Isodictya erinacea & $79.86(2)$ & $68.4(3)$ & $81.75-84.88(18)$ \\
Rossella racovitzae & $86.25(9)$ & $77.1(3)$ & $76.94-95.16(7)$ \\
Rossella nuda & - & $74.6(3)$ & $81.35(16)$ \\
\end{tabular}

stance in demosponges (for a discussion see Barthel 1993). This further reduces the amount of metabolically active tissue in the demosponge species.

The low content of metabolically active tissue in Antarctic sponges results in a low real biomass, even in habitats dominated by sponges. This implies that despite their ubiquitousness, high abundance and large volume, they may channel only a very minor fraction of the flow of matter from the pelagic to the benthic ecosystem. Recent calculations (A. JarreTeichmann pers comm.) support this assumption, but we still lack biomass determinations and metabolic activity measurements to prove il.

gives the following ranges for various tissue composition parameters: DW ( $\%$ WW) 14.5 to 25.4; AFDW ( $\%$ DW), 33.8 to 70.2 ; ash ( $\%$ DW), 29.2 to 66.2 ; ash $(\% \mathrm{WW}), 4.4$ to 14.5 . In other words, the water content is comparatively high in these species, because the content of mineral skeleton is much lower than in the Antarctic sponges investigated in the present study. It seems as if most Antarctic species are characterized by an extremely well-developed mineral skeleton and only a little living tissue. Comparison with data gathered by Dayton et al. (1974) and McClintock (1987) from McMurdo Sound, on the other side of the continent, indicates that this also holds true for other areas of the Antarctic (Table 3). While the data of the present study and those of Dayton et al. are in very good agreement, the values reported by McClintock for spicule (i.e. inorganic) content in the dry matter of sponges from virtually the same site as Dayton's are on average considerably lower. This discrepancy has not as yet been explained. In temperate areas, the tissue composition of sponges varies considerably with season and reproductive cycle (e.g. Barthel 1988), but within the slow-growing Antarctic sponges (Dayton 1979), which probably do not reproduce in a yearly rhythm, we may assume that there is no pronounced seasonal cycle such as that observable in temperate species; organic matter content in Antarctic sponges may be constantly low. Another factor to consider is the proportion of organic skeletal material (spongin, collagen) in the tissue of different sponge species. Hexactinellids contain hardly any skeletal protein (Mackie \& Singla 1983). In contrast, organic skeleton can account for a large portion of the total organic sub-
Dayton et al. (1974) showed for the shallow water of McMurdo Sound that sponges were an important food source for a number of asteroid species and for the nudibranch Austrodoris mcmurdensis, which occurs in high abundances in the habitat. In the Weddell Sea the situation seems to be different in that large potential sponge predators are rare (Table 4). Two of the 5 asteroid species found to feed on sponges in McMurdo Sound do not occur in the eastern Weddell Sea shelf; the other 3 species are much less abundant. Equally rare are browsing and feeding marks on sponges (own obs.). The only sponge predators encountered more regularly are micropredators such as small gastropods and amphipods (Kunzmann 1992). The likely consequence is that most of the energy stored in the form of sponge tissue will ultimately enter the detrital food chain. Thus, the major influence Antarctic sponges have on their habitat is not as mediators of matter or energy flow, but as structuring agents. They add a 3-dimensional structure to an essentially flat environment, serve as habitat for a multitude of small organisms and change substratum conditions by creating a secondary hard substratum with their deposited skeletons (Barthel 1992b)

Table 4. Comparison of densities of known asteroid sponge predators in McMurdo Sound (Dayton et al. 1974) and the eastern Weddell Sea shelf (Voss 1988 , own obs.)

\begin{tabular}{|c|c|c|}
\hline \multirow[t]{2}{*}{ Species } & \multicolumn{2}{|c|}{ Abundance (no. per $1000 \mathrm{~m}^{2}$ ) } \\
\hline & McMurdo Sound & Weddell Sea shelf \\
\hline Odontaster meridionalis & $128 \pm 19$ & $0-5$ \\
\hline Acodontaster conspicuus & $56 \pm 17$ & $0-5$ \\
\hline A. hodgsoni & $3 \pm 5$ & $0-5$ \\
\hline $\begin{array}{l}\text { Perknaster fuscus antarcticus } \\
\text { (adult) }\end{array}$ & 10 & Not found in area \\
\hline $\begin{array}{l}\text { P. fuscus antarcticus } \\
\text { (juvenile) }\end{array}$ & $\sim 10$ & Not found in area \\
\hline
\end{tabular}


Evolutionarily, the high content of mineral skeleton and low amount of living tissue in Antarctic sponges may be a special adaptation to living in cold environments. If this is so, we have to expect similar proportionalities in sponges of Arctic waters and the deep sea.

Acknowledgements. Andrea Detmer, Yasmine Göbel and Cordula Stielau participated substantially in the tissue analysis and data crunching. I sincerely thank them for their support A lively discussion with Paul K. Dayton (one of 'those giants on whose shoulders we stand') helped immensely in formulating the ideas expressed in this paper; I thank him for the encouragement.

\section{LITERATURE CITED}

Arndt W (1930) Schwämme (Porifera, Spongien). In: Oppenheimer C, Pincussen L (eds) Tabulae Biologicae, Vol VI, Suppl II. W Junk, Berlin, p 39-120

Arntz W. Ernst W, Hempel I (eds) (1990) The expedition ANTARKTIS VII/4 (EPOS leg 3) and VII/5 of RV 'Polarstern' in 1989. Ber Polarforsch 68:120-130

Barthel D (1988) On the ecophysiology of the sponge Halichondria panicea in Kiel Bight. II. Biomass, production, energy budget and integration in environmental processes. Mar Ecol Prog Ser 32:291-298

Barthel D (1992a) Antarctic hexactinellids: a taxonomically difficult, but ecologically important benthic component. Verh dt zool Ges 85(2):271-276

Barthel D (1992b) Do hexactinellids structure Antarctic sponge associations? Ophelia 36(2):111-118

Barthel D (1993) Schwämme als Gestalter benthischer Lebensräume. Habilitationthesis, University of Kiel

Barthel D, Gutt J (1992) Sponge associations in the eastern Weddell Sea. Antarct Sci 4(2):137-150

Barthel D, Gutt J, Tendal OS (1991) New information on the biology of Antarctic deep-water sponges derived from underwater photography. Mar Ecol Prog Ser 69:303-307

Barthel D. Tendal OS (1994) Antarctic Hexactinellida. In: Wägele JW, Sieg J (eds) Synopses of the Antarctic benthos, Vol 6. Koeltz Scientific Books, Koenigstein

Barthel D, Tendal OS, Panzer K (1990) Ecology and taxonomy of sponges in the eastern Weddell Sea shelf and slope

This article was presented by $J$. Gray (Senior Editorial Advisor), Oslo, Norway communities, In: Arntz W, Ernst W, Hempel I (eds) The expedition ANTARKTIS VII/4 (EPOS leg 3) and VII/5 of RV 'Polarstern' in 1989. Ber Polarforsch 68:120-130

Beliaev GM, Ushakov PV (1957) Some regularities in the quantitative distribution of the benthic fauna in Antarctic waters. Am Inst Biol Sci Publ 112:116-119 (from Dokl Akad Nauk SSSR Ser Biol 112:137-140, 1957 translationj

Dayton PK (1979) Observations on growth, dispersal and population dynamics of some sponges in McMurdo Sound, Antarctica. In: Vacelet J, Boury-Esnault N (eds) Biologie des Spongiaires. collog int CNRS 291:271-282

Dayton PK, Robilliard GA, Paine RT (1970) Benthic faunal zonation as a result of anchor ice at McMurdo Sound, Antarctica. In: Holdgate $M$ (ed) Antarctic ecology, Vol 1. Academic Press, London, p 244-258

Dayton PK, Robilliard GA, Paine RT, Dayton LB (1974) Biological accommodation in the benthic community at McMurdo Sound, Antarctica. Ecol Monogr 44(1):105-128

Dearborn JH (1977) Foods and feeding characteristics of Antarctic asteroids and ophiuroids. In: Llano GA (ed) Adaptations within Antarctic ecosystems. Proc 3rd SCAR Symp Antarctic Biology. Smithsonian Institute, Washington, DC, p 293-326

Gutt J (1988) Zur Verbreitung und Ökologie der Seegurken (Holothuroidea, Echinodermata) im Weddellmeer (Antarktis). Ber Polarforsch 41

Koltun VM (1969) Porifera. Antarct Map Folio Ser 11:13-14

Koltun VM (1970) Sponges of the Arctic and the Antarctic: a faunistic review. Symp Zool Soc Lond 25:285-297

Kunzmann K (1992) Die mit ausgewählten Schwämmen (Hexactinellida und Demospongiae) aus dem Weddellmeer, Antarktis vergesellschaftete Fauna. Doctoral thesis, University of Kiel

Mackie GO, Singla CL (1983) Studies on hexactinellid sponges. I. Histology of Rhabdocalyptus dawsoni (Lambe, 1873). Phil Trans R Soc Lond B (Biol Sci) 301:365-400

McClintock JB (1987) Investigation of the relationship between invertebrate predation and biochemical composition, energy content, spicule armament and toxicity of benthic sponges at McMurdo Sound, Antarctica. Mar Biol $94: 479-487$

Voss J (1988) Zoogeographie und Gemeinschaftsanalyse des Makrozoobenthos des Weddellmeeres (Antarktis). Ber Polarforsch 45

Wägele JW (1988) Aspects of the life cycle of the Antarctic fish parasite Gnathia calva Vanhoffen (Crustacea Isopoda). Polar Biol 8:287-291

Manuscript first received: November 10, 1994 Revised version accepted: February 22, 1995 